\title{
Ultrasonography and portography in the diagnosis of shunt portoazigos in a dog - case report
}

[Ultrassonografia e portografia no diagnóstico de shunt portoázigos em um cão: relato de caso]

\section{C.J. Santos ${ }^{1}$, R.C. Valadares $^{2}$, R.C.S. Torres ${ }^{3}$, A.C. Nepomuceno ${ }^{3} *$}

${ }^{1}$ Médica veterinária autônoma- Salvador, BA

${ }^{2}$ Médico veterinário - Escola de Veterinária -Universidade Federal de Minas Gerais - Belo Horizonte, MG

${ }^{3}$ Docentes- Escola de Veterinária -Universidade Federal de Minas Gerais - Belo Horizonte, MG

\begin{abstract}
Portosystemic shunt (PSS) is an anomalous vascular connection between the portal venous system and the systemic circulation. These deviations connect the main portal vein (PV) or some portal branches to the vena cava (VC) or, less commonly, to the azygos vein (AV). The purpose of this case report was to describe the diagnosis of PSS in a dog classified as porto-azygos. This diagnosis is considered uncommon compared to other portosystemic shunts using ultrasonography and portography. The subject was a male dog, Yorkshire, 8 months old, presented neurological signs characterized by head press, ataxia, tremors and episodes of temporary blindness and deafness. Ultrasonographic examination revealed a dilated and curved anomalous vessel with approximately $0.6 \mathrm{~cm}$ of diameter and turbulent flow seen through pulsed and color Doppler, and segmental dilation of the azygos vein. The portography revealed enhancement by iodinated contrast in the jejunal vein, the portal vein and an anomalous vessel flowing towards the azygos vein in the craniodorsal region of the abdomen. The PSS was surgically corrected with an ameroid constrictor. Ultrasonography and portography were effective at detecting and characterizing the portoazygos shunt despite some limitations.
\end{abstract}

Keywords: diagnostic imaging, canine, portosystemic deviatio

\section{RESUMO}

Shunt portossistêmico (SPS) é uma comunicação vascular anômala entre o sistema venoso portal e a circulação sistêmica. Esses desvios comunicam a VP ou alguma de suas tributárias à veia cava ou, menos comumente, à veia ázigos (VA). O objetivo do presente estudo foi descrever o diagnóstico, por meio de ultrassonografia e portografia, de um caso de shunt extra-hepático em cão, classificado como portoázigos e considerado incomum quando comparado aos demais tipos de desvio portossistêmico. Um cão, macho, raça Yorkshire, oito meses de idade, chegou ao Hospital Veterinário da Universidade Federal de Minas Gerais apresentando sinais neurológicos, caracterizados por andar apoiando a cabeça na parede, ataxia, tremores, episódios de cegueira e surdez. Ao exame ultrassonográfico, observou-se vaso anômalo calibroso e tortuoso de aproximadamente $0,6 \mathrm{~cm}$ de diâmetro e fluxo turbulento ao Doppler pulsado e colorido, bem como dilatação segmentar da VA. A portografia revelou realce de contraste iodado em veia jejunal, porta e vaso anômalo (shunt) seguindo em direção à VA em região dorsal do abdômen. Foi realizada a correção cirúrgica do SPS por meio de anel ameroide. A ultrassonografia e a portografia foram eficientes na detecção e caracterização do shunt portoázigos, mesmo que com algumas limitações.

Palavras-chave: diagnóstico por imagem, canino, desvio portossistêmico

Recebido em 18 de setembro de 2017

Aceito em 15 de agosto de 2018

*Autor para correspondência (corresponding author)

E-mail: anelise-imagem@ufmg.br 


\section{INTRODUCTION}

Portosystemic shunt (PSS) is an anomalous vascular connection between the portal venous system and the systemic circulation that allows portal blood to enter directly into the systemic veins without passing through the liver. PSS can be classified as congenital or acquired, solitary or multiple, intra or extrahepatic (Thrall, 2014).

PSS is most commonly observed in dogs, although it may occur in cats and other mammals. Extrahepatic congenital PSS is more commonly reported on small dog breeds and cat. Intrahepatic PSS is less prevalent but, seen more frequently in large dog breeds. (Carvalho and Chammas, 2008).

According to a study carried out in Brazil by Carvalho et al. (2009), in which PSS was diagnosed in 20 dogs, $80 \%$ of these animals had portocaval shunt, while $10 \%$ had splenocaval or gastrocaval and only $5 \%$ of the animals presented with the portoazigos shunt.

Clinical signs are related to the gastrointestinal, central nervous and urinary systems. Clinical manifestations combined with laboratory results can suggest the presence of PSS, but it is necessary to identify the abnormal vessel with ultrasonography, portography, computed tomography, scintigraphy and/or exploratory laparotomy (Dyce et al., 2004).

The objective of the case report was to describe the diagnosis using ultrasonography and portography of a portoazygos extrahepatic shunt case, an uncommon diagnosis in dogs when compared to other types of portosystemic shunts.

\section{MATERIAL AND METHODS}

A male Yorkshire dog, 8 months old presented neurological signs characterized by head press, ataxia, tremors, and episodes of temporary blindness and deafness for approximately 45 days. Laboratory tests showed hypoalbuminemia, discrete anemia, decreased urea and creatinine, increased alanine aminotransferase (ALT) and alkaline phosphatase (ALP) enzymes. Thus, clinical suspicion of PSS was raised.
The animal was taken to the ultrasonography sector after previous preparation with fasting and simethicone administration. A wide tricotomy of the abdominal and right intercostal region was performed. For the ultrasound examination, Esaote My Lab 40 equipment was used, with linear $(7.5$ to $12 \mathrm{MHz}$ ) and microconvex (5 to $8 \mathrm{MHz}$ ) multifrequency transducers. Through ultrasound examination it was possible to visualize renomegaly with nephroliths in both kidneys, microhepatia and crystaluria.

With the animal in the left lateral decubitus position, the transducer was positioned in the dorsal paracostal approach, cranial to the right kidney, where anomalous vessel of approximately $0.6 \mathrm{~cm}$ in diameter originated from the PV or one of its tributaries and inserted in an azygos vein (AV), with venous flow. The AV diameter measured approximately $0.46 \mathrm{~cm}$ and it was identified with pulsed and color Doppler. It was directed towards the diaphragm parallel to the AO, where it was not possible to follow it due to pulmonary reverberation (Figure 1). Using color Doppler, the AV flow cranial to the anomalous vessel was very turbulent (characterized by color mosaic) and pulsed Doppler flow was bidirectional with waves above and below the baseline. The PV's flow velocity measured at the region of hepatic hilum, was $11.2 \mathrm{~cm} / \mathrm{s}$, considered normal. This discarded the possibility of portal hypertension.

At the region of hepatic hilum, the transducer was positioned between the 10th and 11th intercostal space. A cross section of the AO, VC and PV was performed on the same plane. Two anomalous vascular structures close to PV and AO (Figure 2) were observed, suggesting that it was a PSS and AV respectively, indicating an extrahepatic portoazygos PSS.

It was possible to measure the diameter of each vessel: $\mathrm{VC}$ measuring $0.56 \mathrm{~cm}$, $\mathrm{AO}$ measuring $0.50 \mathrm{~cm}$ and $\mathrm{PV}$ measuring $0.23 \mathrm{~cm}$. It was possible to observe the decreasing diameter of the PV, cranial to the origin of the shunt, due to the flow that is diverted from that region. The PV / AO ratio was 0.46 . 


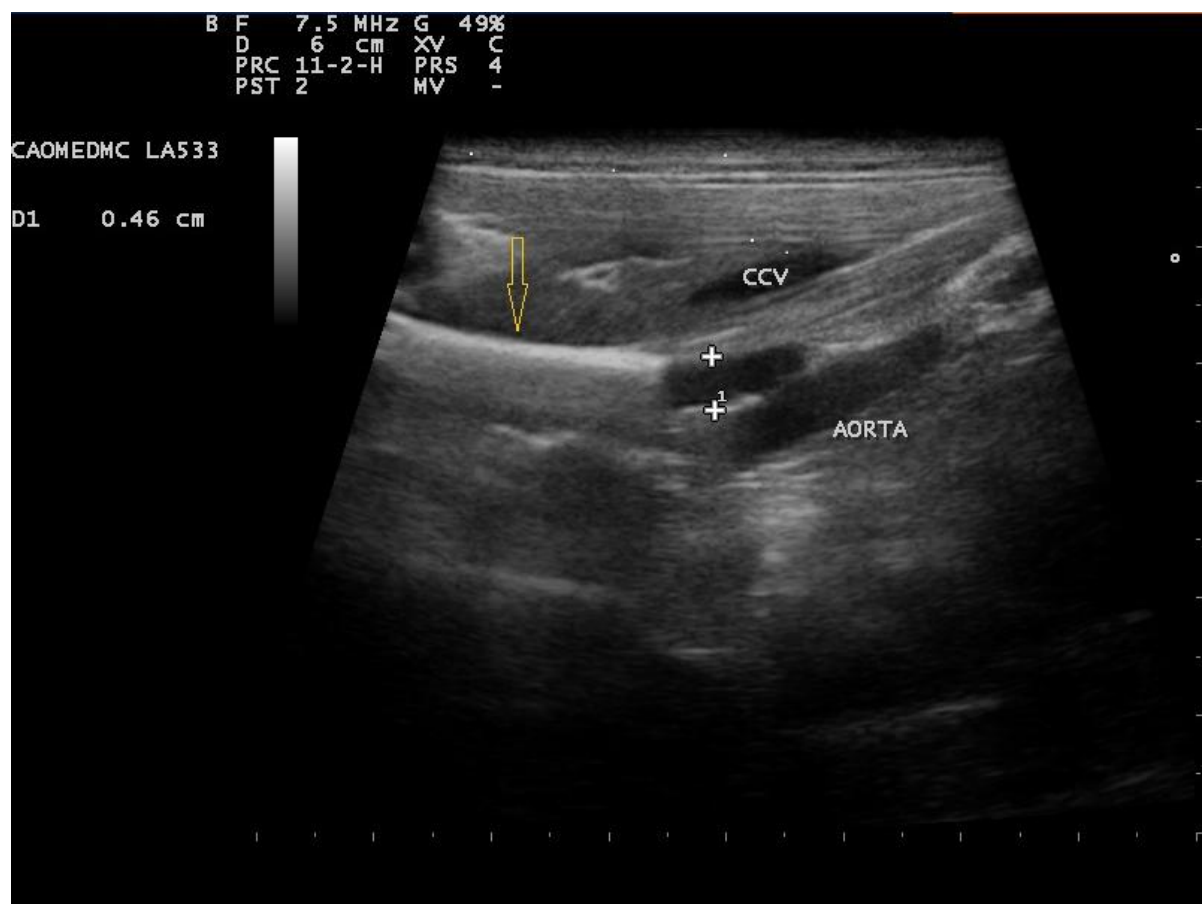

Figure 1. Ultrasound image of dog, Yorkshire, 8 months old. Longitudinal section of vessels representing aortic artery, a dilated azygos vein (cursors) and caudal vena cava (CCV). Diaphragm is visualized as an echogenic line pointed by arrow.

$211 \times 172 \mathrm{~mm}$ (96 x 96DPI).

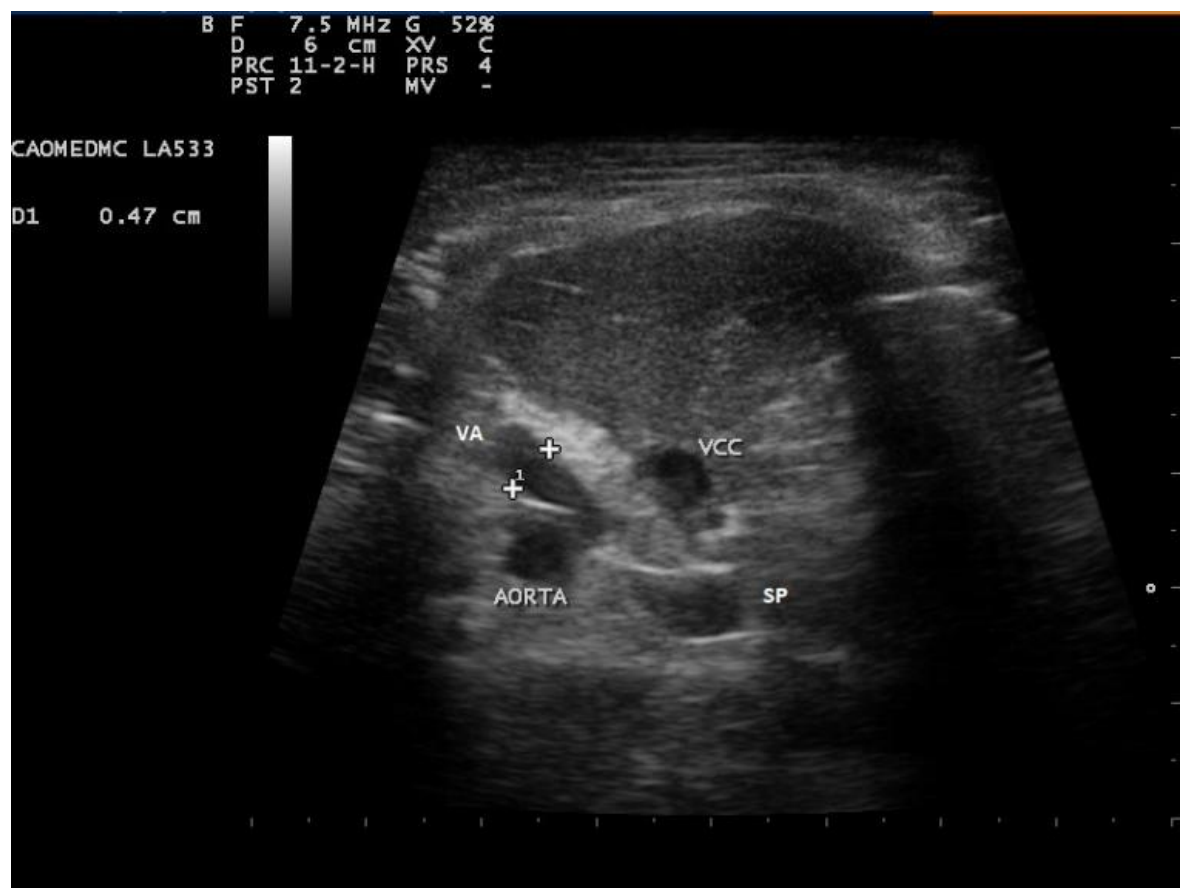

Figure 2. Ultrasound image of dog, Yorkshire, 8 months old. Transverse section at the region of hepatic hilum by intercostal access in the 10th intercostal space. Presence of anomalous vessel compatible with shunt (SP) and dilated azygos vein (VA - cursors) following towards the diaphragm. $211 \times 172 \mathrm{~mm}$ (96 x 96DPI). 
In light of the diagnosis made by ultrasound, we chose to perform mesenteric portography and surgical procedure, in an attempt to correct the vascular deviation. Prior to surgery, the animal was stabilized with lactulose and antibiotic. During the intraoperative period, mesenteric portography was performed. The animal received $1 \mathrm{ml} / \mathrm{kg}$, totaling $5 \mathrm{~mL}$ of iodinated contrast after catheterization of the jejunal vein. A portable X- ray machine EcoRay CO., Ltd $1060 \mathrm{HF}-$ Korea was used. Left lateral decubitus was recommended and radiographic exposures were performed before and after vessel occlusion in agreement with Santilli and Gerboni (2003). Portography confirmed enhancement of iodinated contrast in jejunal veins, portal and anomalous vessels (shunt) in the direction of the AV (Figure 3).

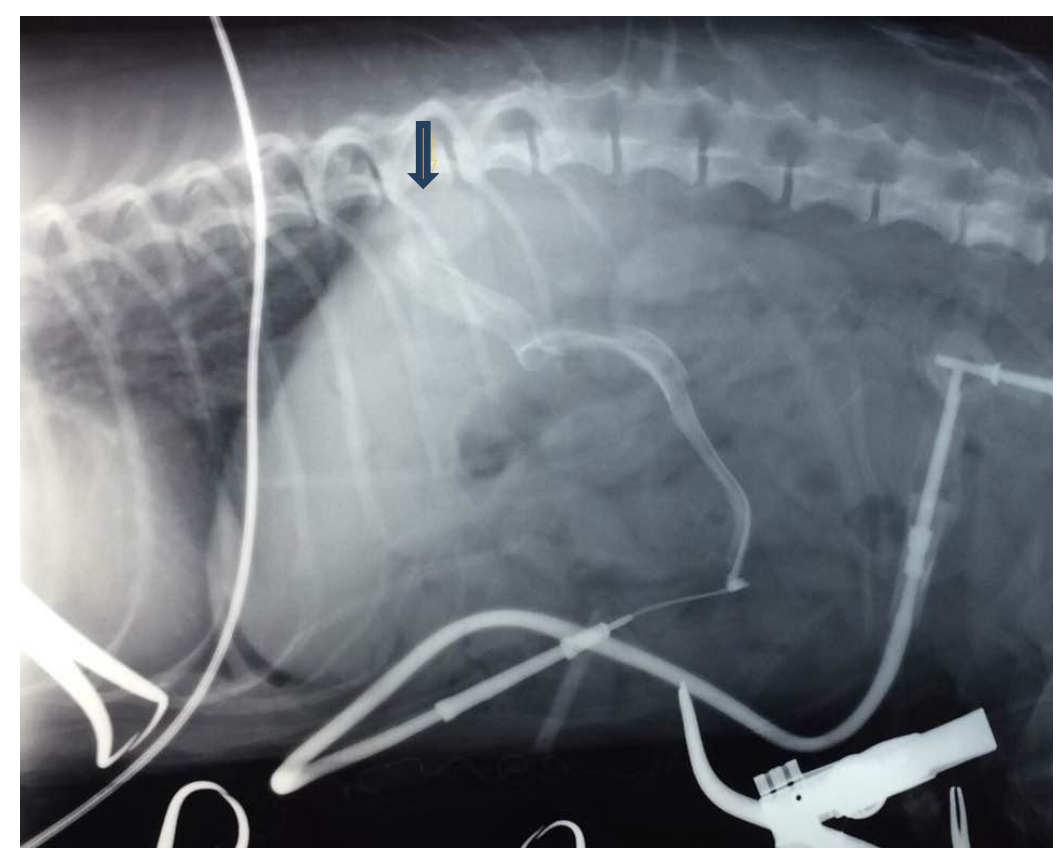

Figure 3. Dog, Yorkshire, 8 months old. Contrasted radiographic examination (portography) demonstrating enhancement of iodinated contrast in jejunal veins, portal and anomalous vessel (shunt) following towards the azygos vein (arrow).

$254 \times 203 \mathrm{~mm}(96 \times 96 \mathrm{DPI})$.

The surgical treatment was based on anomalous vessel occlusion by means of the ameroid constrictor ring, which is made from stainless steel and has a center of hygroscopic casein responsible for gradual intumescence in the first weeks until complete vessel occlusion. This is the treatment of choice for promoting the restoration of the portal flow in a slow manner minimizing the possibility of portal hypertension and shortening surgical time.

\section{DISCUSSION}

In the present report, the Doppler ultrasonographic examination was effective at diagnosing PSS, which reaffirms what was said by D'Anjou et al. (2004) and Lamb (1996) regarding the high sensitivity and specificity of the test in the diagnosis of portosystemic deviations. Ultrasound shunt measurement was also possible, as described by Kamikawa and Bombonato (2012), which was important for choosing the exact ameroid ring diameter for the surgery.

Identification of the portal branch responsible for the shunt origin by ultrasound proved to be difficult, due to the presence of gas in the gastrointestinal tract despite preparation for the examination. In addition, the cranial location of the portoazigos shunt when compared to the majority of portocaval shunts created challenges for ultrasound and surgical accesses.

The limiting factors for the use of the ultrasonographic technique were the requirement 
of an experienced and trained professional, ultrasound equipment with color and pulsed Doppler, knowledge of anatomy and hemodynamics, adequate preparation of the patient, and wide abdominal and thoracic tricotomy, as described by Carvalho and Chammas (2008).

Ultrasonographic diagnosis of PSS requires previous clinical suspicion, as has already been said by Nyland and Matoon (1995), since the location of the anomalous vessel requires a thorough evaluation of the abdominal vascular structures. However, in routine abdominal ultrasonography, venous anomalies should be suspected when microhepatia, renomegaly and urolithiasis are present in young animals (Penninck and D'Anjou, 2015). These findings were also found in the present case report. Another suspicious finding is when any portal tributary has a diameter equal to or larger than the diameter of the main PV. These findings should lead to think about venous anomalies (Nelson and Nelson, 2011).

In the present report, the animal presented PV's flow velocity of $11.2 \mathrm{~cm} / \mathrm{s}$, reaffirming what was said by Kamikawa and Bombonato (2012) in which animals with PSS can have normal PV's flow velocity, ruling out the possibility of portal hypertension. It is important to diagnose portal hypertension to differentiate congenital PSS from the acquired, since the treatments differ (Faverzani et al., 2003).

The PV/AO ratio was 0.46 , corroborating what Penninck and D'Anjou (2015) reported, where the $\mathrm{PV} / \mathrm{AO}$ ratio $\leq 0.65$ is quite suggestive of PSS.

It is possible that the identification of venous deviation is done only by B mode, but the association with Doppler added valuable information about the type, direction and speed of these flows, the differentiation of vessels, in which promoted agility in diagnosis.

The mesenteric portography confirmed the diagnosis of portoazigos shunt suggested by ultrasonography. Through mesenteric portography technique it was possible to map the vascularization, concluding that the dilated vessel observed in the dorsal abdomen at the ultrasound was the dilated AV and not part of the anomalous vessel traversing that region to insert into the thoracic azygos. The use of $5 \mathrm{~mL}$ of contrast was adequate for an excellent blood vessels enhancement in study since it was a small dog, as described by Santilli and Gerboni (2003) who recommended the dose of 5 to $15 \mathrm{ml} /$ animal. However, the portography when performed in the trans-surgical period considerably increases the time of surgery, which is a negative point since in shunt surgeries the anesthesia time is a factor that interferes with the prognosis. In addition, lateral decubitus required for portography (Tobias and Johnston, 2012) was another inconvenience, since the animal was on the surgical table exposed, and a safe and aseptic environment was required for the technique, as reported by Santilli et al. Gerboni (2003).

The surgical procedure was definitive for the diagnosis, although AV access was quite difficult because the vessel location was dorsal in the abdomen and it was superimposed by some organs (Penninck and D'Anjou, 2015), promoting an increase in anesthetic time.

The occurrence of PSS classified as portoazigos is considered low in Brazil (Carvalho et al., 2009), being this a case report uncommonly diagnosed by ultrasonography and portography.

\section{CONCLUSION}

Ultrasonography showed accuracy in the diagnosis of PSS especially since it was used in association with Doppler. However, it required operator experience and detailed anatomical and hemodynamic knowledge as well as patient preparation. Mesenteric portography was also an accurate diagnostic method for PSS, but it was invasive, required a special environment, and increased trans-surgical time. It may be performed separately from the surgical procedure, but the anesthesia may be considered a limiting factor. Both techniques, despite limitations, were exceptionally skillful in the diagnosis of this case report uncommon in the canine species. 


\section{REFERENCES}

CARVALHO, C.F.; CERRI, G.G.; CHAMMAS, M.C. Dopplervelocimetric evaluation of portal vein as a diagnostic tool for portosystemic shunt diagnosis in dogs. Cienc. Rural, v.39, p.14331437, 2009.

CARVALHO, C.F.; CHAMMAS, M.C. Uso do ultra-som dúplex Doppler no diagnóstico de shunt portossistêmico em gatos. Arq. Bras. Med. Vet. Zootec., v.60, p.109-112, 2008.

D'ANJOU, M.A.; PENNINCK, D.; CORNEJO, L. et al. Ultrasonographic diagnosis of portosystemic shunting in dogs and cats. Vet. Radiol. Ultrasound, v.45, p.424-437, 2004.

DYCE, K.M.; SACK, W.O.; WENSING, C.J.G. Tratado de anatomia veterinária: sistema cardiovascular. 3.ed. Rio de Janeiro: Elsevier, 2004. p.512-516.

FAVERZANI, S.; TROMBETTA, R.; GRIECO, V. et al. Clinical, laboratory, ultrasonographic and histopathological findings in dogs affected by portosystemic shunts, following surgery or medical treatment. Vet. Res. Commun., v.27, p.755-758, 2003.

KAMIKAWA, L.; BOMBONATO, P.P. Avaliação morfométrica e hemodinâmica comparativa dos vasos envolvidos no shunt portossistêmico congênito em cães, Pesqui. Vet. Bras., v.32, p.941-946, 2012.
LAMB, C.R. Ultrasonographic diagnosis of congenital portosystemic shunts in dogs: results of a prospective study. Vet. Radiol. Ultrasound, v.37, p.281-288, 1996.

NELSON, N.C.; NELSON, L.L. Anatomy of extrahepatic portossystemic shunts in dogs as determided by computed tomography angiography. Vet. Radiol. Ultrasound, v.52, p.498-506, 2011.

NYLAND, T.G.; MATTOON, J.S. Veterinary diagnostic ultrasound. Philadelphia: Saunders, 1995. p.118-124.

PENNINCK, D.; D’ANJOU, M.A. Atlas of small animal ultrassonography: liver. 2.ed. Ames: John Wiley \& Sons, 2015. p.224-230.

SANTILLI, R.A.; GERBONI, G. Diagnostic imaging of congenital porto-systemic shunts in dogs and cats: a review. Vet. J., v.166, p.7-18, 2003.

THRALL, D.E. Diagnóstico de radiologia veterinária: fígado e baço. 6.ed. Rio de Janeiro: Elsevier, 2014. p.685-686.

TOBIAS, K.M.; JOHNSTON, S.A. Veterinary surgery small animal. 2.ed., St. Louis: Editora Elsevier Saunders, 2432 p, 2012. 